\title{
Skolens etos
}

\section{Nivå eller retning? Lydighet eller motstand?}

\author{
Per Bjørn Foros ${ }^{\star}$ \\ Fakultet for larer- og tolkeutdanning, NTNU, Trondheim, Norge
}

\begin{abstract}
Sammendrag
Artikkelen tar for seg de historiske, kulturelle og samfunnsmessige forutsetningene for pedagogiske hegemonier, skolepolitikk og skolereformer, belyst gjennom tre faser av modernitet (etter Zygmunt Bauman). Det faste moderne kom til å få autoritære utvekster, og skapte i ettertid en angst for pedagogisk autoritet og normativ påvirkning. Dette kom til å prege det flytende moderne, som i sin tur ble anklaget for ambivalens, verdirelativisme og snillisme. Dermed kommer en ny reaksjon, og det utvikler seg fram mot vår tid en ny fasthet, knyttet til prestasjons- og produksjonskrav, kompetanseutvikling og konkurranse, dokumentasjon og kontrolliver. Dette trekker oppmerksomheten bort fra grunnleggende spørsmål om skolens formål og retning, og innebærer tilpasning og lydighet mer enn refleksjon og motstand. Skolens formål må tematiseres på en ny måte, og artikkelen kommer med et bud på nøkkeltemaer i en tidsmessig og samfunnsetisk dannelse, dette i motsetning til ensidig kompetansebygging for et voksenliv i produksionens tjeneste. Mange unge opplever et meningstap under trykket av prestasjons- og presentasjonskravene, og noen ledes til desperasjon og mismot. Skal skole og utdanning bidra til fellesskap og samfunnsbygging, trenger vi en dannelse som gir unge en opplevelse av mening.
\end{abstract}

\section{Nøkkelord: Skolens innhold; fast modernitet; flytende modernitet}

\begin{abstract}
This article analyses the historical, cultural and societal background of hegemonies in education, school politics and school reforms, as observed during three phases of modernity (according to Zygmunt Bauman). Solid modernity has been associated with authoritarian traits, and it caused for decades a confusion concerning teacher authority and moral education. This came to be typical in liquid modernity that in its turn was accused of ambivalence, value relativism and laissez-fair attitudes. Then it was time for a second reaction; towards our time a new solidity developed, celebrating achievement and productivity, competence and competition, testing and assessment. This may take our awareness from questions concerning goals and values. Such goals should be represented in curriculum by key issues, representing crucial ethical questions of our time, different from pure competence aims preparing for adult productivity. Several young people feel a lack of meaning under the burden of self-construction, and some of them suffer from burnout or depression. If school is supposed to contribute to the feeling of being included in society, we need a kind of education that is conceived of as meaningful.
\end{abstract}

^Korrespondanse: Per Bjørn Foros, Vestmarkbakken 8, 7025 Trondheim, E-post: per.bjorn.foros@ gmail.com 
Keywords: School content; solid modernity; liquid modernity

Received: February 2016; Accepted: October 2016; Published: December 2016

I denne artikkelen skal jeg stille to grunnleggende spørsmål om skolens mål og mening. For det første: Har vi blitt så opptatt av nivå at vi forsømmer debatten om skolens retning? For det andre: Fremmer dagens skole en tilbøyelighet til tilpasning og lydighet, på bekostning av kritisk tanke og evne til motstand? Før jeg gir meg i kast med disse spørsmålene, vil jeg legge fram en samfunns- og kulturanalyse som begrunner hvorfor spørsmålenes stilles og hvorfor de henger sammen.

\section{Fra fast til flytende modernitet}

Enhver skolereform må forstås på bakgrunn av sin forhistorie. Slik også med Kunnskapsløftet fra 2006 - og en framtidig reform vil på samme vis si noe om sine historiske forutsetninger. Sosiologen Zygmunt Bauman bruker noen begreper som kan være til nytte $\mathrm{i}$ en slik forståelse. Han snakker om to perioder i vår nære forhistorie, det faste og det flytende moderne (Bauman, 2001), med referanser primært til den europeiske kulturkrets, her med vekt på norsk samfunnsutvikling. Begrepene er ikke å oppfatte som stringente, tidslinjen er omtrentlig, og analysen er snarere dialektisk-polemisk enn konsistent-saklig.

Det faste moderne strekker seg grovt regnet fra 1920 til 1970, med de første par tiårene preget av økonomisk krise, høy arbeidsledighet, store klasseforskjeller og sosial uro, så kommer krigen og deretter gjenreisning og framveksten av en moderne velferdsstat. Ikke så rart at denne perioden krevde faste grep - og at det kunne trenges forestillinger om noe bedre. Dette nedfelte seg i visse kjerneverdier. Karakteristisk var hangen til visshet, knyttet til politiske ismer og vitenskapelig positivisme, overbevisning i sak og begeistring under fanene. En uttalt styringsiver kom til uttrykk i politisk handlekraft, sterk statsmakt og institusjonell kontroll over individene (skolevesen, psykiatri). I alle livets forhold gjaldt det å ha orden i sakene, enten det var i hjem, skole eller arbeidsliv. Tryggheten var å finne i en forutsigbar verden, der målet var like rettigheter og verdige levevilkår for alle - innenfor en nasjonal velferdsstat. Men de store ideer hadde sine utvekster. Slik kunne vissheten bli til meningsterror, styringsiveren til overgrep, orden til manier og likhet til ensretting. Denne fastheten preget også skolen i det samme tidsrommet (Foros, 2006). Dens praksis var det sosiologen Basil Bernstein kaller en «synlig» pedagogikk, med klare krav, klare kriterier for vurdering og klare roller (Bernstein, 1977).

Men nye tider var i emning. Med freden kom demokratiske strømninger og løpende økonomisk vekst. Nettopp derfor vokste det også fram en uro over visse trekk ved det faste moderne, dets rådende autoriteter og det etablerte samfunn. Det symbolske vendepunktet var studentopprøret i 1968, men samfunnskritikken kom til å ta to ulike retninger (Boltanski \& Chiapello, 2005). Sosialkritikken var rettet mot sosial og økonomisk ulikhet og mot de strukturelle årsakene til slik ulikhet, med en visjon om frigjøring av de undertrykte og utbyttede. Kunstnerkritikken var mer 
opptatt av uniformeringen i massesamfunnet, konsumjaget og kommersialiseringen av menneskelige relasjoner; den sprang ut av kulturell opposisjon mer enn av politisk motstand. Målet var frigjøring av den enkelte, individuell autonomi, det autentiske og unike. Bakgrunnen for radikalismen på 1970-tallet finner vi primært i sosialkritikken. Studenter okkuperte auditoriene, ungdommen la seg i lenker mot naturødeleggelser, og feminisme, fredsbevegelse og solidaritetsprosjekter blomstret. Men sosialkritikken og den politiske radikalismen forstummet, mens både pedagogikken og venstresiden lot seg friste av de mer livsnytende strømningene som fulgte kunstnerkritikken.

For det var en forskjell på den personlige frigjøringen kunstnerkritikken så for seg og den politiske frigjøringen sosialkritikken etterlyste. Den første - med sin vekt på frihet og utfoldelse - viste seg å passe som hånd i hanske med den nyliberalistiske bølgen som flommet innover oss på 1980-tallet, og som var en reaksjon på idealene fra det faste moderne - stat, styring og likhet - til fordel for marked, frihet og individ.

Dermed er vi midt inne i det flytende moderne, som fikk sin begynnelse på 1970tallet og strekker seg inn i vår tid. I store trekk er dette sammenfallende med det som også har vært kalt det postmoderne. Men det moderne var selvsagt ikke slutt, det endret bare karakter, og det vokste fram andre forestillinger, uttrykt som negasjoner til det faste moderne og hele dets vesen. Nå er det ikke lenger visshet og enhet som gjelder; det er ambivalens og tvetydighet, kulturelt mangfold og normativ toleranse. Styringsiveren taper for økende frihetstrang, og jakten på valg og muligheter overtar. Forestillinger om orden og oversikt taper terreng; vi snakker heller om fleksibilitet og omstilling. Og fellesskapet skranter, til fordel for den enkeltes interesser. Verden og verdiene er kommet $\mathrm{i}$ bevegelse. Men også her finner vi utvekster: Tvil og ambivalensen kunne bli til likegyldighet, frihetsidealene til kravmentalitet og egoisme; fleksibilitet og omstillingskrav kunne lede til utmattelse, og individkulten til forestillinger om den sterkestes rett.

Disse trekkene finner vi igjen i skolen (Foros, 2006). Nå kommer den åpne pedagogikken, som ikke bare handler om at klasserommet og skoleklassene forsvinner, men om tverrfaglighet, lærersamarbeid og elevsentrering. Bernstein karakteriserer dette som en «usynlig» pedagogikk, der kravene blir utydelige, tilhørigheten viskes ut og rollene blir uklare. Også kunnskapen endrer karakter; dens klassifikasjon og struktur blir løsere (Bernstein, 1977).

Ikke bare blir kunnskapen omdefinert; det oppstår samtidig en forestilling om at det er i metodene hemmeligheten ligger. En hel flora av nye begreper vokser fram: samarbeidslæring, aksjonslæring, erfaringsbasert læring, ansvar for egen læring, problembasert læring, prosjektarbeid, læringsstil - og redskapet over alle redskaper: IKT. Dette henger sammen med at også kunnskapen er blitt usikker. Dens univers foreldes og utvides i raskt tempo, og inntrykks- og informasjonsstrømmen øker og øker. Da oppstår denne tanken: Etter hvert som kunnskapen blir mer flyktig - altså mindre oversiktlig og enhetlig - må vi søke til mer robuste faktorer i læringsprosessen, nemlig allmenngyldige metoder, strategier og ferdigheter. Vi søker etter måter å lære på som er slik at hvis du klarer deg i én situasjon, kan du også beherske andre. Da kan metodene 
overføres utvungent fra den ene konteksten til den andre. Det som gjelder, er selve evnen til å lære; elevene skal «lære å lære». Dermed blir læreren mindre viktig, det nye mantraet kom til å bli «ansvar for egen læring», og vi begynte å snakke om laring i stedet for undervisning.

Her er det vanskelig å skille klinten fra hveten; det vrimler av uklare begreper, teoriene vanskelige å forstå, de er vanskelige å omsette i praksis, og de stiller store krav til praktisk organisering. På dette viset kommer læringsmålene fort i bakgrunnen. Når kunnskapen ikke lenger er gitt og mangfoldet overtar, peker fordringene mot den enkelte; kunnskapen må skapes av den enkelte. Denne utviklingen avspeiler en mer generell teoribygning i det flytende moderne - nemlig konstruktivismen - en fellesbetegnelse for de forestillingene som går ut på at vi selv konstruerer vår virkelighet, vår kunnskap, vår identitet og vår livsmening.

Alt $\mathrm{i}$ alt er vi vitne til en forskyvning fra innhold til form, en bevegelse som er karakteristisk for det flytende moderne, der opplevelsen tar over for opplysning, estetikken for etikken, ironien for de klare meninger. I skolen ytrer dette skiftet seg på andre vis, noe som danner bakgrunn for skillet mellom materiale og formale danningsteorier (Klafki, 2001). Materiale teorier setter kultur, fag og undervisningens innhold i sentrum, mens formale teorier kretser om barnet, metodene og undervisningens form. Hegemoniet i det flytende moderne innehas av formale danningsteorier.

På 1980-tallet - under formalismens høykonjunktur - flommet det en romantisk bølge innover skolen, ifølge sosiologen Ove Skarpenes (2007). Nå får vi høre om identitet, helhet, selvbevissthet, selvrealisering og ansvar - ikke så langt fra reformpedagogikkens tanke om barnets iboende krefter, men begrunnet på en helt annen måte. Den humanistiske tanken om individets egenverdi og ukrenkelighet blir gradvis erstattet av autentisitet og selvtilstrekkelighet. Barn måtte ikke være autoritetsbundet, bli pålagt krav og eller underkaste seg tvang; dette var «stopprammer» som hindret barna i deres utfoldelse.

\section{Den nye fastheten}

Det kom etter hvert til å oppstå en slitasje under det flytende moderne. Tapet av strukturer, den utbredte relativismen og snillismen - alt dette usikre og tilbakelente blir etter hvert utsatt for kritikk. Og store samfunnsproblemer tårner seg opp knyttet til miljø, økonomi og kulturkonflikter - som på nytt reiser spørsmålet om hvor vi vil i skole og samfunn. Dermed er det duket for det jeg kaller den nye fastheten, som ble mer og mer synlig fra århundreskiftet.

Den ytrer seg på mange områder. I vitenskapen som en ny jakt på visshet (biologisme, nypositivisme), i offentlig sektor (etter modell fra næringslivet) som New Public Management (krav - konkurranse - kontroll), i jussen som dreining i rettsoppfatning (skjerpet straffeutmåling, snevrere kriterier for utilregnelighet), i velferdsordningene som strengere krav til mottakere (fokus på trygdemisbruk, krav om egeninnsats), i samfunnskontroll som økt overvåkning (sporing av terror og kriminalitet, fotfølging av barn og eldre) eller som ønsket om en tøffere ordensmakt 
(politibevæpning, tiggerforbud, grensekontroller) og i kulturell forstand som kritikk av multikulturalismen (krav til norskhet).

Heller ikke her er skolen noe unntak, og reaksjonen måtte komme. Men den kom fra andre hold enn dem som har stått nærmest skolen. Det har hersket en påtakelig unnfallenhet blant majoriteten av fagpedagoger og på den politiske venstresiden når det gjelder to temaer i skoledebatten: lærerens autoritet og kunnskapens betydning. I den pedagogiske debatten har vi hatt to klare fronter. De progressive pedagogene har stilt barnet $\mathrm{i}$ sentrum, med vekt på trivsel, utfoldelse og fri aktivitet, mens de restaurative pedagogene har angrepet den progressive pedagogikken for å ha sviktet kunnskapen (Telhaug, 1992). De første har - gjennom sin frihetsromantikk utilsiktet tjent liberalistiske trender; de andre er - på grunn av sin retorikk om krav og prestasjoner - blitt tatt til inntekt for næringslivets interesser. Sjelden har noen stilt det grunnleggende spørsmålet: Hva skal vi bruke kunnskapen til? Dermed er arenaen blitt overlatt til næringslivet og den politiske høyresiden, som har kommet til å dominere den skolepolitiske debatten og dermed peke ut den nye kursen for skolen. Den har dreid seg om å heve kunnskapsnivået, ikke så mye om retningen.

Det var Gudmund Hernes som var først ute. I NOU 1988:28 Med viten og vilje (1988) kom han med følgende programerklæring: «Utfordringen for norsk kunnskapspolitikk er at landet ikke får nok kompetanse ut av befolkningens talent», og hans ambisjoner viste seg i fagplanene fra 1997 (L97). Her var kunnskapens mål klart uttrykt og inntil smerteterskelen tydeliggjort gjennom detaljerte krav knyttet til fag og alderstrinn. Kompetansen var knyttet til kunnskap, i motsetning til det som skulle komme gjennom neste reform. Samtidig sørget Hernes for et danningsrettet innhold i den generelle delen av planverket: Mennesket skal være meningssøkende, skapende, arbeidende, allmenndannet, samarbeidende og miljøbevisst. Og grunnlaget ligger i den nasjonale kulturarven, fremmet gjennom et felles lærestoff. Kort sagt: Vi aner dobbeltheten av kompetanse og danning.

Her skal skytes inn at danningsbegrepet lenge var uglesett både i den pedagogiske og politiske verden, koblet som det var til tilbakeskuende, borgerlige og elitistiske idealer. Begrepet brukes ikke i L97. Hernes tyr i stedet til oppfostring, som er en gjenganger i den generelle delen av planverket. Men det er begrepet kompetanse som nå gjelder. I stortingsmelding nr. 30 (2003-2004), Kultur for laring, som ligger til grunn for Kunnskapsløftet, forekommer ordet hele 540 ganger. Vi møter det 199 ganger $\mathrm{i}$ de påfølgende fagplanene (K06). I den skolepolitiske debatten snakket en heller om kunnskap; skoleverket hadde sviktet kunnskapen, og kunnskapen måtte gjenopprettes, men ingen snakket om danning. I Kunnskapsløftet beholdes den generelle (og danningsorienterte) delen fra L97, men innpakningen gjennom fagplanene er radikalt forskjellig i sin retorikk. Det ligger en spenning i terminologien knyttet til det nye planverket; fagplanene kretser om kompetanse, reformens betegnelse refererer til kunnskap. Hva ligger i begrepene? Hva er det som har skjedd?

La oss først se på kunnskapen. Under forarbeidet til K06 ble det gjort et stort poeng av at kravene til kunnskap skulle skjerpes; de skulle bli klarere og mer forpliktende. Så viser det seg at det i mindre grad handler om kunnskaper enn om ferdigheter. I retningslinjene for planarbeidet (Utdanningsdirektoratet, 2004, s. 10) 
blir det advart mot formuleringer som peker i retning av kunnskap (ha kjennskap til, innsikt i), og i stedet pålagt å legge vekt på arbeidet med faget (giøre, utføre) - altså aktiviteter og ferdigheter.

Særlig sentralt står grunnleggende ferdigheter: å kunne lese, uttrykke seg muntlig og skriftlig, regne og beherske digitale verktøy. Men ferdighetene strekker seg lenger; de omfatter også overordnede strategier for læring og generelle læringsferdigheter. Dette er en forlengelse av tanken om robuste ferdigheter stilt overfor kunnskapens flyktighet (se denne artikkel s. 5). Begge deler, både vekten på grunnleggende ferdigheter og generelle læringsferdigheter, har bidratt til at den skolefaglige substansen er blitt mer uklar - selv om det varierer noe fra fag til fag - og språket i fagplanene avspeiler dreiningen.

La oss bruke samfunnsfag og delemnet historie som eksempel. I L97 (fagplanen) finner vi slike formuleringer: Eleven skal utvikle kjennskap til, skaffe seg oversikt over, få innsikt $i$, hente inn kunnskap om, gjøre seg kjent med, arbeide med, reflektere over. Så følger detaljerte krav til hva en skal ha kunnskap om. I K06 heter det at elevene skal «beskrive, undersøke, utforske, forklare». Men det elevene skal arbeide med, er vagt angitt. Svært få historiske fenomener er omtalt; ikke engang 1814 eller 1905 er nevnt. Det står ikke et ord om de to verdenskrigene, om kommunismens fall eller om Midt-Østen. Derimot skal elevene lære seg å presentere utviklingstrekk, analysere konflikter, formulere årsaksforklaringer, diskutere konsekvenser av konfliktene og reflektere over omveltningene i dagens samfunn.

Norskfaget er både et kulturfag og et ferdighetsfag. Det er ikke vanskelig å se at de grunnleggende ferdighetene (lese, skrive, kommunisere) er viktige forutsetninger for danning. Men tilknytningen blir uklar, når planen i stor grad mangler materiale referanser. Innenfor litteraturfeltet er det ikke angitt noen forfatternavn, litterære verk, stilretninger eller perioder, mens det står en hel del om tekstanalyse og lesestrategier, litterære temaer, sjangere og leseopplevelse. Så spørs det om lærerne ser sammenbindingen mellom ferdigheter og formål, det vil si om ferdighetene vil tjene danningen eller blir formaløvelser løsrevet fra overordnede formål. Eller enda snevrere: de reduseres til målbar og nyttig kompetanse.

Det faktum at det legges så stor vekt på ferdigheter og at sammenbindingen mellom ferdigheter og formål er uklar, bidrar til å gjøre hele planverket uklart. Alt i alt er det vanskelig å se at presisjonsnivået er høyere i K06 enn i L97. En kan saktens si at det står for mye i L97, og at det svekker graden av forpliktelse. Men at kunnskapskravene er lavere, er det ikke grunnlag for å hevde.

Den samme utvikling har skjedd i Danmark. Det fins dem som mener at kompetansekravene i folkeskolereformen fra $2014 \mathrm{er}$ en forutsetning for et moderne danningsprosjekt, blant dem Jens Rasmussen (Rasmussen, Holm \& Rasch-Christensen 2015), som samtidig er en av reformens arkitekter. Det er denne oppfatningen filosofen Peter Kemp kaller Løgnen om dannelse (2015), i det han framhever den ulike rollen kunnskapen har i en nyttebegrunnet kompetanseutvikling - som han anser for å være reformens hovedformål - og et humanistisk danningsprosjekt. 


\section{Frukter av den nye fastheten}

Hvordan har det så gått med oss under den nye fastheten? La oss først se på kulturbildet i sin helhet. Når vi ser den nye biopositivismen utfolde seg - forankret i evolusjonsbiologi, nevrovitenskap og kropp - kan det virke som vår menneskeforståelse er i ferd med å innsnevres. Tradisjonelle oppfatninger av hva mennesket er bevissthet, valg, egenverd, fellesskap - synes å være på vikende front. Når denne mentalitetsendringen opptrer sammen med produktivitetspresset $\mathrm{i}$ det faste moderne og nytte blir alle tings mål, kommer tanken om menneskets danning til kort. Rent paradoksalt blir det når kontrolliveren knyttet til resultatpresset skjer på bekostning av den friheten vi ellers setter så høyt. Ja, kan kravene til oss alle bli større enn vi tåler?

Slik også når det gjelder andre trekk ved den nye fastheten - hvor forståelige de enn måtte være som reaksjon mot det flytende moderne: Kan de slå over i fenomener vi ikke liker? Vil dreiningen i rettsoppfatning kunne lede til en avhumanisering av rettsvesenet, kan tilstrammingen i velferdsordninger føre til en svakere velferdsstat? Hva gjør økt overvåkning og væpnet politi med oss som samfunnsborgere? Og hva med uroen ved det kulturelle mangfold: Kan kravene til nasjonal enhet true toleranse og mangfold? Hvis disse bekymringene er berettigede, er jeg redd vi er vitne til en ny fase i det moderne - der den nye fastheten blir til hardhet.

Og hva med de unge? På de premissene som ligger skjult i den nye fastheten (disiplinering, prestasjon, konkurranse) har det vært en vellykket mentalitetsendring. I skolen var det en betydelig framgang i resultatene på PISA-prøvene mellom 2006 og 2009, en framgang som riktignok har stagnert ifølge de siste undersøkelsene; til gjengjeld er norske skoleelever mer lydige og bråker mindre i klasserommet (Kjærnsli \& Olsen, 2013), lovbrudd blant unge har gått ned de siste årene (Statistisk sentralbyrå, 2013), og bruken av alkohol og cannabis er redusert i samme periode (Nasjonalt folkehelseinstitutt, 2014). Ja, de lever også sunnere, trener mer og kler seg skikkelig (Norsk institutt for forskning om oppvekst, velferd og aldring, 2014). I det hele tatt framstår den unge generasjonen - «generasjon $\mathrm{Z}$ » eller «generasjon perfekt» - som disiplinert, målrettet og uklanderlig. I Danmark snakkes det om «den nye ordentligheten».

Det fins en bakside av medaljen. I forlengelsen av resultatpresset i skolen endrer hele regimet karakter. Det grunnleggende spørsmålet er blitt: What works? Hva er det som gir resultater? Det snakkes på nytt om «synlighet» i undervisningen (Hattie, 2012), altså klarhet i mål og vurderingskriterier. Målet er «no child left behind». Også Bernsteins anklage på 1970-tallet mot «den usynlige pedagogikken» var begrunnet $i$ at usynligheten gikk ut over marginalelevene $i$ skolen, ikke minst de som kom fra sosiale lag som var fremmede overfor middelklassens skole og den åpne pedagogikken. Men den gang var det ingen test- og kontrollmani knyttet til begrepet, og det er grunn til å frykte at den nye synligheten like mye som å støtte marginalelevene kan true dem gjennom sin begrunnelse i treenigheten kravkonkurranse-kontroll. 


\section{Per Bjørn Foros}

I samsvar med fokuseringen på målbarhet og konkurranseevne i skole og arbeidsliv ser vi at prioritering og valg av skole- og utdanningsveier endrer seg. I grunnskolen er det fagene som er gjenstand for målinger, som vinner terreng, både i lærernes oppmerksomhet og i timetall. I høyere utdanning taper humaniora, kunst- og kulturfagene og i noen grad samfunnsfagene, både når det gjelder budsjetter, studietilbud og studievalg. Det vil si at noen av de fagene som særlig innbyr til refleksjon og kritisk tenkning, er i ferd med å bli andrerangs. Også frafallet i videregående skole, der bare to tredjedeler av guttene fullførte i perioden 2008-2013 (Statistisk sentralbyrå, 2014), er fristende å sette i sammenheng med resultatpress og fremmedgjøring i skolen.

Direkte skremmende blir det når vi ser på økningen av psykiske lidelser blant unge, noe det ikke er urimelig å knytte til slitasjen under stressfaktorene vi snakker om. Bruken av antidepressiva øker, stadig flere unge rapporterer om psykiske plager, og et økende antall mottar trygdeytelser på grunn av psykiske lidelser (Nasjonalt folkehelseinstitutt, 2014). Men det kan stikke dypere. Den danske psykologen Nadja Prætorius snakker om et meningstapsom ikke bare forsterker den psykiske påkjenningen, men som også skaper livsproblemer og framtidsangstangst (2014).

Den norske sosiologen Gunnar C. Aakvaag skrev i 2013 en kronikk i Aftenposten der han lanserte begrepet «generasjon lydig». Aakvaag, selv årgang 1972, etterlyste kritisk samfunnsengasjement hos dagens unge. Men det kan godt være at disse ungdommene - stilt overfor dagens samfunn og sin egen framtid - snarere bryr seg for mye, er redde og kjenner seg alene. Det er lettere å søke kontroll innenfor en avgrenset sfære, seg selv, eget utseende, egen kropp, eget liv. Sosiologen Rasmus Willig snakker om «kritikkens u-vending» i sin bok med samme tittel (2013). Her beskriver han endringen i de unges livsverden; samfunnskritikken er blitt til selvkritikk. «Systemet» er hinsides den enkeltes kritikk; det avpolitiseres og framstår som noe gitt.

Er det da så rart om de unge søker mening utenfor dette systemet, velger avvik framfor tilpasning og søker til ekstreme miljøer (religiøse, ideologiske, politiske) som tilbyr både mening, identitet og tilhørighet? Det er i lys av dette vi må forstå norsk rekruttering til grupper som IS, som er forlokkende nettopp på dette grunnlaget. De unge er altså villige til å gå langt for å få innfridd elementære sosiale og eksistensielle behov.

\section{Hva med skolen?}

Med bakgrunn i analysen ovenfor skal jeg stille to grunnleggende spørsmål når det gjelder skolen. Det første tar utgangspunkt i prestasjonspresset, og får meg til å spørre: Har vi blitt så opptatt av kunnskapens nivå at vi forsømmer debatten om skolens retning?

Den ene siden ved dette er kampen om oppmerksomhet i det daglige: Jo mer tid og krefter som går med til et stort kontrollbyråkrati, jo mer svekkes lærerrollen knyttet til danning. I tillegg er det åpenbart slik at de nasjonale prøvene legger føringer for undervisningen og stjeler oppmerksomhet fra danningskravene i læreplanene. På et 
mer overordnet plan er det grunn til å spørre: Hvordan skal ytre interesser avspeile seg i skolen - næringslivets versus samfunnets? Eller mer konkret: Hva er forskjellen på krav knyttet til produktivitet og konkurranse versus krav knyttet til danning og fellesskap?

Kunnskapsløftet opererer med et kompetansebegrep som i stor grad avspeiler kravene til produktiv kunnskap. I mindre grad finner vi en refleksjon om hva som trengs for å møte utfordringene i vår tid, og hva som kan synliggjøre valg og vurderinger vi står overfor. Vi trenger en tematisering og en kontekstualisering av hva det står imellom. I sin teori om dialektisk danning snakker Wolfgang Klafki (2001) om såkalte nøkkeltemaer, temaer som fanger de vesentlige spørsmål i vår tid og som konfronterer den enkelte med samfunnet han eller hun er en del av. Dialektikken ligger $i$ forholdet mellom temaenes innhold og den refleksive måten å granske dem på (material - formal), og i møtet mellom eleven og verden.

Det såkalte Ludvigsenutvalget har nettopp avgitt sin innstilling, under tittelen Framtidens skole. Fornyelse av fag og kompetanser (NOU 2015: 8). Utvalgets mandat var - som det framgår av tittelen - å utrede fagenes innhold og organisering ut fra de utfordringer skoleverket står overfor. Når det gjelder innholdet, er det vanskelig å få tak på hva utvalget mener. Det anbefales en oppmykning av kompetanse- og ferdighetsbegrepet, men samtidig er det slik at formalismen på nytt sniker seg inn, gjennom begreper som «lære å lære» og «metakognisjon» (bevisstgjøring av egen læring). Det viktigste ved utvalgets arbeid ligger etter mitt skjønn i erkjennelsen av at skolens innhold er fragmentert og at elevenes læring er overflatisk; utvalget argumenterer i stedet for en tydeligere tematisering og fordypning i det vesentlige. Dette faller sammen med resonnementet jeg har lagt fram.

Sammen med Arne Johan Vetlesen har jeg i boka Angsten for oppdragelse. Et samfunnsetisk perspektiv på dannelse (Foros \& Vetlesen, 2015) prøvd å konkretisere noen berende temaer, som er ment å ramme inn vesentlige områder for fordypning, og som i neste omgang kan danne bakgrunn for skolens læreplaner. Disse temaene er skjematisert i tabellen nedenfor.

\section{Økologisk danning}

Nærhet til natur

Opplevelser og erfaringer i naturen

Natur som egenverdi og kulturbakgrunn

Vern om liv

Respekt for liv og livsformer

Sårbarhet og gjensidighet

Menneskets rolle og ansvar

\section{Økonomisk danning}

Vekst og kostnader

Mat- og vareproduksjon

Innsatsfaktorer og utbytte

Eksponentiell vekst

Målestokker for økonomi

Miljø- og framtidskostnader

Arbeid og velferd

Forutsetninger for velferdsstaten

Innsats og krav

Produksjon og slitasje 
Per Bjørn Foros

Erkjennelse av grenser

Naturgrunnlag og ressurser

Tømming av kilder

Tetting av sluk

Naturens tålegrenser og bærekraft

Fordeling av godene

Interessekonflikter og klasseforskjeller

Skjevfordeling og urettferdighet

Likeverd og solidaritet

\section{Teknologisk danning}

Politisk danning

Teknologiens dobbelthet

Nytte og ulemper

Gevinster som spises opp

Robusthet og risiko

Kulturelle konsekvenser

Verdimessige dilemmaer

\section{Digitale medier}

Meningsdanning og nettkultur

Kilde- og informasjonsvurdering

Misbruk og avhengighet

Sikkerhet og risiko

Kontroll og overvåkning

\section{Kulturell danning}

Identitet og fellesskap

Røtter og tilhørighet vs. mobilitet og mangfold

Nasjonal enhet - hva er det?

Borgerfellesskap i et multikulturelt samfunn

Kulturkonflikter og fremmedfrykt

Globalisering på godt og vondt

Kulturelle uttrykk og kreativ utfoldelse

Rikdommen i kulturens verden

Kunst- og kulturuttrykk

Opplevelser og deltakelse

Kulturell selvrefleksjon

Kulturhistorie, kulturarv

Uro og oppbrudd

Jeg ser for meg at disse temaene kan utgiøre et overordnet perspektiv som nedfelles i lære- og fagplaner. Hvis det i fagplanene blir synliggjort hvilke valg, konflikter og verdispørsmål som skal tas opp i hvert fag - og i tillegg blir krevd en avveining, enn si et standpunkt - kan dette i en viss forstand kalles normativt. Men det er noe helt annet enn at standpunktene blir elevene pålagt. 
Dette må også få konsekvenser for vurdering av læring. Hvordan elevene er i stand til å bruke kunnskaper og ferdigheter i meningsfylte sammenhenger, er mer viktig enn deres gjengivelse av kunnskap og dokumentasjon av ferdigheter gjennom avgrensede og formelle prøver. Men vi må altså være i stand til å synliggjøre mål og kriterier, slik John Hattie etterlyser synlighet i undervisningen (se denne artikkel s. 7), men på andre premisser enn bare effektivitet og resultater. Det avgjørende spørsmålet er hva som gir mest meningsfylt undervisning for flest mulig.

Det andre hovedspørsmålet om skolens rolle er dette: Fremmer dagens skole en tilbøyelighet til tilpasning og lydighet, på bekostning av kritisk tanke og evne til motstand? I en skole som prioriterer nivå framfor retning, målbarhet framfor refleksjon, er det mye som taler for at vi fremmer tilpasning og lydighet, men trenger det å være slik at dette er uforenlig med motstand?

Begrepene er vanskelige. Det er grunn til å etterlyse en klarere autoritet blant foreldre og lærere, i oppdragelse og danning. Men skal da ikke en slik autoritet nettopp avle tilpasning? På den andre side: Når en etterlyser motstand, ligger det vel implisitt at en ønsker motstand mot det en ikke liker - og lydighet overfor normene en selv vedkjenner seg til? Det hele koker ned til at begrepene autoritet, lydighet og motstand er avhengige av kontekst og verdigrunnlag. Begrepene er tvetydige, og står og faller med sine formål. De avgjørende spørsmålene er derfor: Hvilken autoritet? Motstand mot hva? Lydighet mot hvem? Oppdragelse i hvilken retning? Det er denne debatten vi mangler.

Heller ikke er det åpenbart hvorvidt den motstanden en ønsker seg, skal rette seg mot nye trender og utviklingstrekk, eller om den skal rette seg mot det bestående og etablerte samfunn. Det første er en «konservativ» motstand, det andre gir assosiasjoner til det «radikale». I sin bok Stå fast. Et opgør med tidens udviklingstvang (2014) erklærer Sven Brinkmann seg i stor grad til den konservative motstand. Hans hovedbudskap er: Si nei! Dvel ved fortiden! Det kan være lett å la seg rive med av slike tanker, men det betyr ikke at jeg - og det giør vel heller ikke Brinkmann overser problemene ved det bestående. Det er jo dette samfunnet som har ført oss inn i den krisen vi beskriver. En annen sak er at det konservative i dag - i noen spørsmål - kan fortone seg som radikalt, nettopp fordi det innebærer en motstand mot rådende trender.

En forståelse av motstand trenger altså ikke å være historisk betinget; det vil til alle tider være nødvendig å utøve motstand. Like viktig er det at unge møter motstand, som godt kan være en betingelse for selv å øve motstand. Der har vi sviktet de unge, sier den danske sosiologen Henrik Dahl - med referanse til det flytende moderne:

Vores problem er slet ikke resterne af undertrykkelse i den moderne verden, men at leve med friheden $\mathrm{i}$ den postmoderne verden. Vores kollektive bevidshed tager udgangspunkt i, at der kan argumenteres så vel for som imod hva som heldst, og at alting derfor i principet kan lade sig gøre. Hvor både forældrene og pædagogerne måtte kæmpe mod undertrykkelsen, så må vi kæmpe ikke mod friheden, men imod dens illusioner (Dahl, 1998, s. 58). 
Dahl retter en kritisk pekefinger mot sin foreldregenerasjon, som har skaffet barn all denne friheten:

Forudsætningen for at man kan gennemføre denne udviklingen (mot selvstendighet), er for det første, at ens forældre er til stede og for det andet, at de gør modstand. Uden kvalificeret modstand kommer der til at mangle konsekvens og dybde i sælvstendiggørelsen (Dahl, 1998, s. 92).

Tanken om at det er viktig å øve motstand, er det mange som deler. Men det er et stort sprang å omsette denne tanken til oppdragelse og danning. Det er dette som må være vårt prosjekt, og det synes mer aktuelt enn noen gang. Er potensialet for motstand større enn vi evner å se? Og kan forutsetningene for motstand vokse fram?

I pedagogisk forstand handler det i første omgang om å oppdra til moralsk skjønn og dømmekraft - som er den minst vanskelige løsning. For da er vi innenfor pedagogisk mainstream, der vi flittig oppfordrer eleven til å vurdere hva som er riktig og galt. Men så må vi forvente at slik vurdering omsettes i aktiv motstand. Det viktige er å klargjøre hvilke moralske valg vi står overfor; det er dette som er formålet for de bærende temaer ovenfor (se denne artikkel s. 9f.), der vekten er lagt på å klarlegge valgene. Så går det i tillegg an å håpe på at det i samfunnet som helhet skjer en verdimessig kursendring som nedfelles $i$ holdninger hos foreldre og et klarere mandat for skolen, slik at selve grunnlaget for oppdragelse og danning endrer karakter. Det kan godt være at dette skjer snarere enn vi tror - hvis det først bygger seg opp en kollektiv kriseforståelse.

Den unge danske filosofen og økonomen Finn Janning (2009, s. 124) sier det slik, på vegne av generasjonen som skal overta verden:

Modstand handler om at skabe et fundament, som en bedre verden kan vokse frem af. Aldri som en blind troskab overfor en position, heller ikke i opposition, hvilket meget modstand fejlaktig reduceres til. Snarere en konstant blottelse. Ingen forbedring finder sted uden denne blottelse, der kræver stort mod. Al utvikling sker i kraft af en blottelse. En åbenhed overfor det, som ikke er en selv, det ukendte, det fremmede. Det vi ikke umiddelbart kan forstå, men vil forstå. Fordi det ukendte og fremmede måske kan vise sig at skabe et bedre fundament, et tredje sted, hvorfra kommende generasjoner kan skabe ny livsglede.

\section{Ungdommens veier}

I det jeg har skrevet, ligger det en oppfatning av at vår samtid kan være vanskelig å forholde seg til for de unge, og at de står overfor en usikker framtid. Det mest alarmerende er opplevelsen av meningstap. Men som vi har sett, er det mange som ikke bekymrer seg i det hele tatt - og snarere tilpasser seg krav og forventninger de møter. For noen kan dette grense til likegyldighet; de fortrenger realitetene og fornekter handlingsmulighetene. I så fall er prisen høy. For mismotet, en nær slektning av likegyldigheten, kan lure like rundt hjørnet. Depressive uttrykk ser ut til å bre om seg blant dagens unge, og framtidsangsten stikker ofte fram. De fleste voksne rygger tilbake for å snakke med de unge om deres uro, dessuten er det pedagogisk ukorrekt: 
Vi må ikke ta fra de unge troen på framtida. Gjennom unnfallenheten bidrar vi bare til at uroen blir ytterligere fortrengt.

Alternativet til mismot er opprør. Det kan ytre seg både som stillfarende opposisjon og som støyende aksjon, som utprøvende livsstil og erklært revolusjon. Det spenner fra ubehjelpelig iver til bevisste motkulturer. Når mismot blir til avmakt, kan det gro fram ekstreme miljøer som tilbyr både utageringsmuligheter og identitet. Vi kan finne dem som nisjer innenfor store aksjonsmiljøer, slik vi ser steinkasterne i kamp med politiet under protestopptogene mot Verdensbanken, Pengefondet og G7-landenes politikk, eller når utålmodige miljøvernere blir fristet til gateopptøyer, slik vi så under Parisforhandlingene i desember 2015.

Jeg har argumentert for at oppdragelse og danning må inneholde en kime til opprør, til motstand, slik at de unge får muligheter og inspirasjon til å kunne stå imot ytre press av ulike slag, for slik å bli trygge på seg selv og bygge egen integritet eller en evne til myndighet, som et nødvendig korrektiv til et begrep om det autentiske som de siste tiårene er kapret av nyliberal ideologi og blitt integrert i diktatet om tilpasning.

Motstand mot etablert makt og dominerende meninger må, for å virke konstruktivt og skape endring på måter som er ønskverdige for fellesskapet, springe ut av refleksjon og samfunnsengasjement snarere enn av desperasjon. Og hvis engasjement skal vare og opprør bli konstruktivt, trengs det et minimum av tillit til voksne, især de som bekler lederroller. Her er det ikke bare en amerikansk president, en norsk statsminister eller en konserndirektør som har en jobb å gjøre; det har også vi som er modeller for de unge $\mathrm{i}$ våre roller som foreldre og lærere. Hvis tilliten mellom generasjonene svikter, kan motstanden ta former og en retning vi ikke ønsker. Hvis tilliten derimot næres og bygges, kan vi håpe på at de unge klarer å sortere: tilpasse seg og være lydige overfor det beste i vår kultur, men øve motstand mot det som ikke fortjener det. Begrunnet kontinuitet, begrunnet oppbrudd!

\section{Biografi}

Forfatteren er tidligere førsteamanuensis ved Høgskolen i Sør-Trøndelag (nå NTNU), der han har undervist i pedagogikk og miljøfag. Han har skrevet en rekke bøker, og deltar gjerne i offentlig debatt, både når det gjelder utdanning, miljøspørsmål og politiske temaer, gjerne ispedd kulturfilosofiske betraktninger, og med særlig interesse for menneskets dannelse.

\section{Referanser}

Bauman, Z. (2001). Flytende modernitet. Oslo: Vidarforlaget.

Bernstein, B. (1977). Class, Codes and Control. London: Routledge \& Kegan Paul.

Brinkmann, S. (2014). Stå fast. Et opgør med tidens udviklingstvang. København: Gyldendal Business.

Dahl, H. (1998). Den kronologiske uskyld - historien om den generation der blev født voksen. København: Gyldendal.

Foros, P.B. (2006). Skolen i klemme. Dilemmaer og spenningsforhold. Oslo: Cappelen Akademisk Forlag.

Foros, P.B. \& Vetlesen, A.J. (2015). Angsten for oppdragelse. Et samfunnsetisk perspektiv på dannelse. (2. utgave). Oslo: Universitetsforlaget.

Boltanski, L. \& Chiapello, E. (2005). The New Spirit of Capitalism. London: Verso.

Hattie, J. (2012). Visible Learning for Teachers: Maximizing Impact on Learning. New York: Routledge.

Janning, F. (2009). Modstand. Århus: Klim.

Kemp, P. (2015). Løgnen om dannelse. København: Tiderne skifter. 
Kjærnsli, M., \& Olsen, R. V. (2013). Fortsatt en vei å gå. Norske elevers kompetanse $i$ matematikk, naturfag og lesing i PISA 2012. Oslo: Universitetsforlaget.

Klafki, W. (2001). Dannelsesteori og didaktikk. Nye studier. København: Klim forlag.

Lereplanverket for den 10-årige grunnskolen (L97). Oslo: Kirke- undervisning- og forskningsdepartementet.

Nasjonalt folkehelseinstitutt (2014). Folkehelserapporten 2014.

Norsk institutt for forskning om oppvekst, velferd og aldring (NOVA) (2014). Ungdata. Nasjonale resultater 2013.

NOU 1988: 28 Med viten og vilje. Oslo: Kulturdepartementet.

NOU 2015: 8 Framtidens skole. Fornyelse av fag og kompetanser. Oslo: Kunnskapsdepartementet.

Prætorius, N. U. (2014). «Omstillingens etiske udfordring». I K. Illeris (Red.), Laring i konkurrencestaten. Kapløb eller bceredyktighed. Frederiksberg: Samfundslitteratur.

Rasmussen, J., Holm, C. \& Rasch-Christensen, A. (2015). Folkeskolen - efter reformen. København: Hans Reitzel.

Skarpenes, O. (2007). Kunnskapens legitimering. Oslo: Abstrakt.

Statistisk sentralbyrå (2013). Anmeldte lovbrudd 2012.

Statistisk sentralbyrå (2014). Gjennomstrømning $i$ videregående opplcering, 2009-2013.

St. meld. nr. 30 (2003-2004). Kultur for laring. Oslo: Det kongelige forsknings- og utdanningsdepartement.

Telhaug, A. O. (1992). Norsk og internasjonal skoleutvikling. Oslo: Ad Notam Gyldendal.

Utdanningsdirektoratet (2004). Retningslinjer for arbeid med lcereplaner for fag.

Utdannings- og forskningsdepartementet (2006). Kunnskapsløftet. Lareplan for grunnskolen og videregående opplaring. (K06) Oslo: Utdannings- og forskningsdepartementet.

Willig, R. (2013). Kritikens u-vending. En diagnose af forvandlingen fra samfundskritik til selvkritik. København: Hans Reitzels forlag

Aakvaag, G. (2013). «Hva skal dagens ungdom bruke stemmeretten til?». Kronikk i Aftenposten, 01.09.2013. 